\title{
Sistem Monitoring Digital Penggunaan dan Kualitas Kekeruhan Air PDAM Berbasis Mikrokontroler ATMega328 Menggunakan Sensor Aliran Air dan Sensor Fotodiode
}

\author{
Muhammad Kautsar ${ }^{1)}$, R. Rizal Isnanto, ${ }^{2)}$., Eko Didik Widianto ${ }^{2)}$ \\ Program Studi Sistem Komputer Fakultas Teknik Universitas Diponegoro \\ Jalan Prof. Sudharto, Tembalang, Semarang, Indonesia \\ em.kautsar@ce.undip.ac.id
}

\begin{abstract}
Abstrack Water became one of the staples in the community who are taking a very important role in life. Dependence of human life should not need to denied of water presence. Many activities of human dependent of water such as drinking, washing, bathing etc. In the city, PDAM as a service business into regional water supply solution to deliver water in the houses. Currently, the use of an analog water meter is ineffective for the custumer to be able to monitor the use of water consumption and bill to be paid. Not only that, sometimes the quality of water delivered by the service is not good, it can be seen during the rainy season, which causes the water to become turbid. Today's technology much shift something analog to digital which is better appearence and easier operation. Thus in this study designed a digital monitoring system using based on microcontroller ATMega 328 by measuring the water discharge from the tube's connection. For measuring the water usage using the water flow sensor that uses the principle of the hall effect. At the same tool can detect water turbidity problems using photodiode sensor which have working principle by intensity of light received from sample reservoir. The output of this system contains information on water discharge, volume of water in cubic meter also is added to the unit of price. Result of testing the accuracy sensor water flow reached $98,8 \%$ while sensor photodiode had scale measurement water turbidity reacehed 0 - 173 NTU.
\end{abstract}

Key words : Monitoring System, Microcontroller ATMega328, Water flow sensor, Water turbidity, Photodiode.

\section{PENDAhUluan}

Air merupakan bagian kebutuhan pokok manusia yang banyak digunakan untuk memenuhi aktivitas sehari-hari seperti minum, mandi, mencuci dan lain sebagainya. Di perkotaan, pelayanan jasa air bersih umumnya diselenggarakan oleh pemerintah melalui PDAM (Perusahaan Daerah Air Minum). Air yang disalurkan oleh PDAM ke rumah-rumah penduduk biasanya berasal dari pengununggan yang mengalir ke sungai kemudian di tampung terlebih dahulu di bak-bak penampungan (reservoir) kemudian di saring dan di distribusikan ke rumah-rumah pelanggan ${ }^{[1]}$.

Dewasa ini, masalah utama sumber daya air meliputi kuantitas air yang mampu memenuhi kebutuhan manusia yang terus meningkat dan kualitas air untuk menjamin hal tersebut kini sudah amat parah. Banyak industri-industri yang mencemari daerah tangkapan air baik itu sungai dan air bawah tanah. Meningkatnya penebangan pohon-pohon di hutan menjadi faktor sebab terjadinya penurunan kualitas sumber daya air.

Peningkatan kuantitas air merupakan syarat kedua setelah kualitas, karena semakin maju tingkat hidup seseorang, maka akan semakin tinggi pula tingkat kebutuhan air dari masyarakat tersebut ${ }^{[2]}$. Untuk keperluan minum sendiri dibutuhkan air rata-rata 5 liter/hari, sedangkan secara keseluruhan kebutuhan akan air suatu rumah tangga untuk masyarakat Indonesia diperkirakan 60 liter/hari. Jadi, bagi negara yang sudah maju kebutuhan air pasti lebih besar dari kebutuhan negara-negara yang sedang berkembang ${ }^{[3]}$.

Akibat penurunan kualitas air tanah, menyebabkan banyak masyarakat yang beralih menggunakan air PAM untuk memenuhi kebutuhan sehari-hari. Meskipun demikian PDAM (Perusahaan Daerah Air Minum) belum mampu melayani kebutuhan air bersih untuk seluruh masyarakat, masih banyak dijumpai fakta di lapangan bahwa kadar air yang di salurkan PAM (Perusahaan Air Minum) mengalami pencemaran baik bersifat kimiawi, bakteriologis maupun fisiologis. Secara fisiologis parameter yang dapat dijumpai dengan terjadinya perubahan warna, bau, rasa, suhu dan kekeruhan.

Kekeruhan merupakan sifat optik dari suatu larutan yang menyebabkan cahaya yang melaluinya terabsorbsi dan terbias. Air akan dikatakan keruh apabila air tersebut mengandung begitu banyak partikel bahan yang tersuspensi, sehingga memberikan warna atau rupa yang berlumpur dan kotor ${ }^{[4]}$. Air keruh yang tidak tembus pandang menyatakan bahwa air tersebut memiliki tingkat kekeruhan yang sangat tinggi sedangkan air yang tembus pandang memiliki kekeruhan yang rendah. Bahan-bahan yang menyebabkan kekeruhan ini meliputi tanah liat, lumpur, pasir halus dan bahan-bahan organik.

Di era yang serba maju ini banyak teknologi yang dijumpai berbasis digital, dimana dalam ini dimunkinkan untuk dapat menjamin efisiensi waktu dan tenaga serta manajemen dengan baik. Oleh karena itu banyak orang lebih cederung memlilih teknologi digital karena mempuyai banyak keuntunggan baik dari segi ergonomi dan penggunaanya yang mudah.

Oleh karena itu perlu dibuat sebuah alat secara elektronik yang dapat memantau penggunaan volume air sekaligus mengkonversinya ke dalam satuan harga yang di tempatkan di rumah pelanggan sehingga pelanggan dapat dengan mudah memantau penggunaan air yang mereka gunakan secara akurat. Sistem ini juga dapat dikembangkan dengan pendeteksian kekeruhan air yang ditempatkan pada saluran pipa air. Sistem pengendalian yang digunakan pada penelitian ini menggunakan mikrokontroler ATMega 328 dengan papan sirkuit Arduino Nano versi 3.0.

\section{TINJAUAN PUSTAKA}

\section{A. Gambaran Umum Air}

Air merupakan sumber daya alam yang sangat penting dalam kehidupan manusia dan digunakan banyak masyarakat untuk berbagai kegiatan sehari-hari, termasuk dalam bidang 
pertanian, perikanan, industri pertambangan, rekreasi, dan sebagainya. Tanpa air tidak akan ada kehidupan di muka bumi ini, karena setiap makhluk hidup berasal dari air dan membutuhkan air untuk bertahan hidup.

\section{B. Kualitas Air}

Air bersih adalah air yang digunakan untuk keperluan sehari-hari yang kualitasnya memenuhi syarat kesehatan dan dapat diminum apabila telah dimasak ${ }^{[5]}$. Standar kualitas tersebut ditunjukan oleh parameter kualitas air, yaitu fisika, kimia, mikrobiologi atau bakteriologi dan radiologi. Tabel 1 menunjukkan parameter fisika kulitas air. Namun, fokus pada makalah ini hanya menjelaskan masalah kekeruhan air.

Tabel 1. Persyaratan parameter fisika kualitas air bersih

\begin{tabular}{|l|c|c|l|}
\hline Parameter Fisika & Satuan & Kadar Max & Keterangan \\
\hline Suhu & $\mathrm{C}$ & Suhu udara \pm 3 & - \\
\hline Rasa & - & - & Tidak berasa \\
\hline Kekeruhan & $\begin{array}{l}\text { Skala } \\
\text { NTU }\end{array}$ & 5 & - \\
\hline $\begin{array}{l}\text { Jumlah zat padat } \\
\text { terlarut }\end{array}$ & $\mathrm{Mg} / \mathrm{l}$ & 500 & - \\
\hline Bau & - & - & Tidak berbau \\
\hline Warna & SkalaTCU & 15 & - \\
\hline
\end{tabular}

Kekeruhan adalah suatu bentuk pengukuran cahaya yang tersebar dari interaksi yang tersuspensi dan material terlarut pada sampel air, hal ini menjadikan sebagai indikator kualitas air. Kekeruhan juga dapat didefinisikan sebagai pengurangan transparansi cahaya pada sebuah cairan yang disebabkan oleh partikel-partikel yang terlarut.

Kekeruhan dinyatakan dalam satuan tubinitas yang setara dengan $1 \mathrm{mg} / \mathrm{l} \mathrm{SiO} 2$. Peralatan pertama kali yang digunakan untuk mengukur turbinitas atau kekeruhan adalah Jacson Candler Turbidimeter, yang dikalibrasi dengan silika. Jacson Candle Turbidimeter dijadikan sebagai alat baku atau standar bagi pengukuran kekeruhan. Satu unit turbinitas dinyatakan dengan 1 JTU. Pengukuran kekeruhan dengan menggunakan Jacson Candle Turbidimeter berisfat visual, yaitu membandingkan air sample dengan standar.

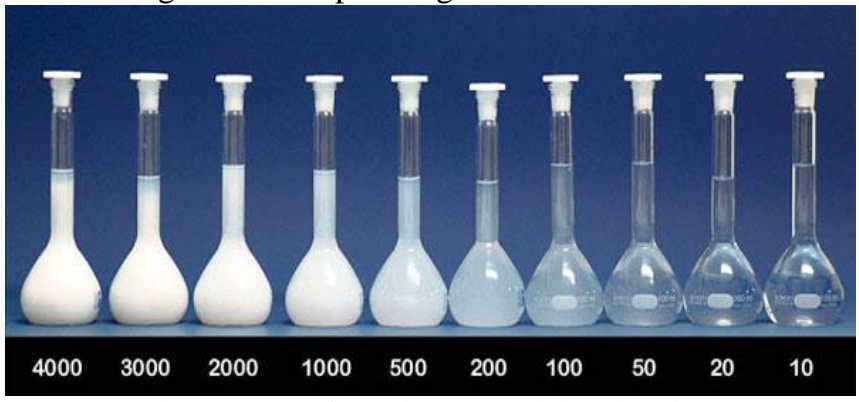

Gambar 1. Standar formazin suspense kekeruhan air NTU

Selain dengan menggunakan Jacson Candle Turbidimeter, kekeruhan sering diukur dengan metode Nephelometic. Pada metode ini, sumber cahaya dilewatkan pada sampel dan intensitas cahaya yang dipantulkan oleh bahan-bahan penyebab kekeruhan diukur dengan menggunakan suspensi polimer formazin sebagai larutan standar, semakin tinggi intensitas cahaya dihamburkan maka semakin tinggi pula kekeruhannya. Satuan kekeruhan yang diukur dengan menggunakan Nephelometric adalah NTU (Nepheleometric Turbinity Unit). Satuan JTU dan NTU sebenarnya sama saja tidak dapat saling mengkonversi ${ }^{[6]}$.

Standar kekeruhan pada air yang tergenang, misalnya danau lebih banyak disebabkan oleh bahan tersupensi yang berupa koloid dan partikel-partikel halus. Sedangkan kekeruhan pada sungai yang sedang banjir banyak disebabkan oleh bahan-bahan tersupensi yang berukuran lebih besar, yang berupa lapisan permukaan tanah yang terbawa oleh aliran air pada saat hujan. Kekeruhan yang tinggi dapat mengakibatkan tergangunya sistem osmoregulasi misalnya, pernafasan dan daya lihat organisme akuatik, serta dapat memghambat daya penetrasi cahaya kedalam air.

\section{Debit}

Debit air (discharge) atau besarnya aliran sungai (stream flow) adalah volume aliran yang mengalir melalui suatu penampang melintang sungai persatuan waktu ${ }^{[7]}$. Debit air sendiri biasanya dinyatakan dalam satuan meter kubik per detik $\left(\mathrm{m}^{3} /\right.$ detik) atau liter per detik (1/detik). Aliran adalah pergerakan air di dalam aliran sungai.

Kekurang telitian atau kesalahan (errors) pengukuran debit dapat diartikan sebagai besarnya nilai perbedaan antara debit yang dihitung berdasarkan pengukuran dengan debit yang sebenarnya. Kesalahan pengukuran debit umumnya bersumber dari dua macam sebab yaitu kesalahan petugas dan kesalahan peralatan. Berbicara tentang kesalahan maka kesalahan juga dapat dibedakan antara ketepatan dan ketelitian ${ }^{[8]}$.

\section{Arduino Nano Versi 3.0}

Arduino adalah salah satu produk papan elektronik yang mengandung sebuah mikrokontroler AVR yang menjadi sebuah kesatuan atau biasa dikenal dengan sistem minimum. Arduino merupakan sebuah modul pepan pengembang yang sifatnya terbuka (open-source), fleksibel, dan mudah digunakan dalam hal perangkat keras dan perangkat lunak ${ }^{[9]}$. Gambar 2 menujukan bentuk fisik dari Arduino Nano V3.0, sedangkan Tabel 2 mendeskripsikan spesifikasi dari Arduino.

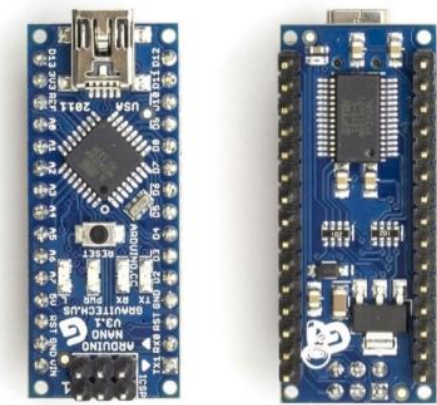

Gambar 2. Arduino Nano Vesi 3.0

Tabel 2. Spesifikasi Arduino Nano 3.0

\begin{tabular}{|l|l|}
\hline \multicolumn{1}{|c|}{ Komponen } & \multicolumn{1}{c|}{ Keterangan } \\
\hline Mikrokontroler & Atmel ATMega328 \\
\hline Tegangan Operasi & $5 \mathrm{~V}$ \\
\hline Tegangan Input & $7-12 \mathrm{~V}$ \\
\hline Batas Tegangan Input & $6-20 \mathrm{~V}$ \\
\hline Digital I/0 & 14 Pin (tersedia 6 keluaran PWM) \\
\hline Analog Input & 8 Pin \\
\hline DC Current per I/O pin & $40 \mathrm{~mA}$ \\
\hline Flash Memori & $32 \mathrm{~KB}$ (ATmega328), 2 KB \\
& bootloader \\
\hline SRAM & $2 \mathrm{~KB}$ \\
\hline EEPROM & $1 \mathrm{~KB}$ \\
\hline Kecepatan Clock & $16 \mathrm{MHz}$ \\
\hline Dimensi & 0.73 ' $1.70 ”$ \\
\hline
\end{tabular}

\section{E. ATMega 328-AU}

ATMega 328-AU adalah sebuah mikrokontroler keluaran dari Atmel jenis TQFP-32 dengan bentuk minimalis. 
Mikrokontroler ini juga merupakan bagian seri ATMega328P, yang mempuyai arsitektur CPU berbasis RISC (Reduce Instruction Set Computer), dimana setiap proses eksekusi data lebih cepat dari pada arsitektur CISC (Completed Instruktion Set Computer) ${ }^{[10]}$. Selain itu pada mikrokontroler ini tersedia komponen ADC yang dapat mengkonversi sinyal analog ke digital dengan resolusi pengukuran $0-1023$ bit/second.

\section{F. Sensor Aliran Air}

Sensor aliran air terdiri dari tubuh katup plastik, rotor air, dan sensor hall efek. Ketika air mengalir melalui rotornya, rotor akan berputar. Kecepatan putarannya bersesuian dengan rata-rata kecepatan aliran air yang melaluinya. Sensor efek hall akan menghasilkan pulsa-pulsa digital yang bersesuian dengan kecepatan rotor.

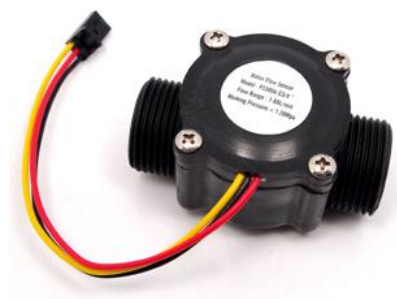

Gambar 3. Sensor Aliran Air

\section{G. Sensor Fotodiode}

Fotodiode adalah komponen elektronik yang terbuat dari bahan semikonduktor berbeda dengan diode biasa, komponen elektronika ini akan mengubah cahaya menjadi arus listrik. Cahaya yang dapat dideteksi oleh fotodiode ini mulai dari cahaya inframerah, cahaya tampak, ultra ungu sampai sinar-X. Prisnip kerja fotodiode jika terkena cahaya, maka akan bersifat sebagai sumber tegangan dan nilai resistansinya akan menjadi kecil. Sebaliknya jika fotodiode tidak terkena cahaya, maka nilai resistansinya akan semakin besar atau dapat diasumsikan tak hingga. Besarnya tegangan atau arus listrik yang dihasilkan fotodiode tergantung besar kecilnya radiasi yang di pancarkan oleh sumber cahaya.

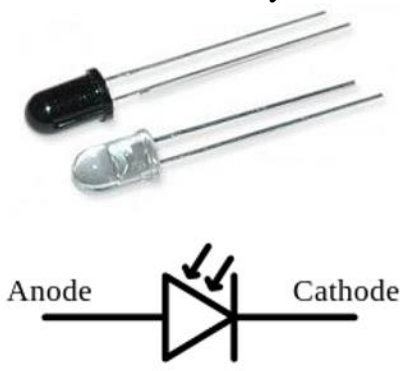

Gambar 4. Sensor Fotodiode

\section{PERANCANGAN SISTEM}

\section{A. .Spesifikasi kebutuhan fungsional}

Spesifikasi kebutuhan fungsional dilakukan untuk memberi gambaran tentang alat yang akan dibuat dapat berfungsi sesuai dengan yang diinginkan. Kebutuhan fungsional dalam pembuatan tugas akhir ini sebagai berikut.

1) Alat menggunakan mikrokontroler ATMega 328 sebagai pusat kontrol untuk membaca nilai akuisisi sensor.

2) Alat mampu menampilakan informasi pembacaan sensor aliran air dan mengkonversi ke volume dan biaya yang dikenakan pada LCD.
3) Alat mampu menampilkan informasi pembacaan sensor fotodiode dan mengubah ke variabel linguistik pada LCD.

4) Alat mampu menampilkan derajat kekeruhan air melalui indikator LED.

\section{B. Sepesifikasi kebutuhan Non Fungsional}

Kebutuhan non-fungsional mendeskripsikan tingkatan dari kualitas. Kebutuhan non-fungsional dari pembuatan Tugas Akhir ini adalah sebagai berikut.

1) Purwarupa alat dibuat sedemikian rupa sehingga memudahkan dalam proses pemasangan dan penggunaannya.

2) Kontruksi purwarupa alat terintegrasi pada pipa paralon $1 / 2$ inci.

3) Catu daya yang dibutukan oleh alat adalah berkisar 6 - 12 Volt.

\section{Perancangan perangkat keras}

Perancangan perangkat keras berhubungan dengan pebuatan sistem secara nyata, yang dimulai dengan mendefinisikan kebutuhan sistem sampai perakitan komponen-komponen elektronik dan mekanik. Untuk diagram blok sistem dapat dilihat pada Gambar 5.

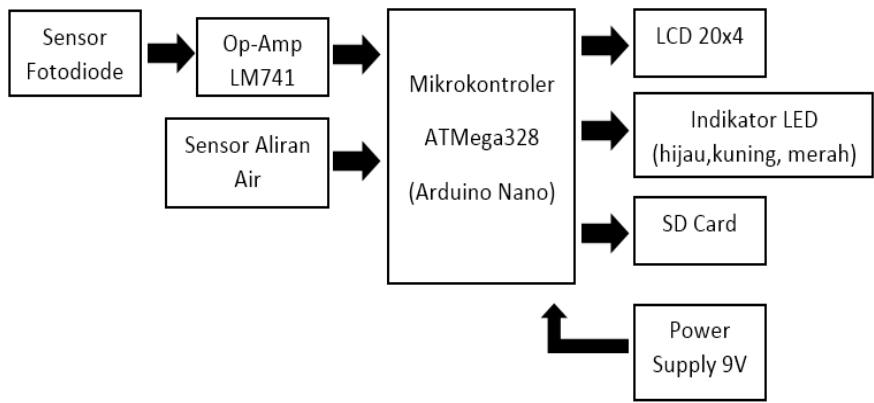

Gambar 5. Diagram blok sistem

\section{Perancangan Sistem Minimum Arduino Nano}

Sistem minimun yang dirancang menggunakan papan pengembang Arduino Nano versi 3.0 dengan mikrokontroler berbasis ATMega328 yang telah melekat didalamnya. Alasan penggunaan papan ini karena ukurannya yang minimalis dan mudah untuk dipasang pada breadboard serta dilengkapi dengan port mini-B USB. Pada Arduino Nano, sistem minimum sudah ditunjang oleh beberapa komponen yang umum seperti regulator DC 5 volt, tombol reset, oscilator, LED indikator dan rangkaian ICSP (In Circuit System Programming). Berikut merupakan bentuk skematik rancangan sistem minimum yang terdapat pada Arduino Nano versi 3.0.

Untuk perancangan perangkat keras secara keseluruhan sistem, dilengkapi dengan interkoneksi masukan sensor aliran air, sensor fotodiode, LED dan button sedangkan untuk keluarannya berupa antarmuka LCD. Adapun skematiknya dapat dilihat pada Gambar 6, sedangkan penggunaan pin Arduino dapat dilihat pada Tabel 3.

Tabel 3. Penggunaan pin pada Arduino

\begin{tabular}{|l|l|}
\hline Pin Arduino Nano & \multicolumn{1}{c|}{ Komponen } \\
\hline D2 & Sensor Aliran Air \\
\hline D3 - D8 & LCD \\
\hline D10-D13 & Modul SD Card \\
\hline A0 - A2 & Indikator LED \\
\hline A3 & LEDx \\
\hline A6 & Fotodiode \\
\hline A7 & Op-Amp \\
\hline Vcc, Gnd, ARef & Catu daya 5 Volt \\
\hline
\end{tabular}




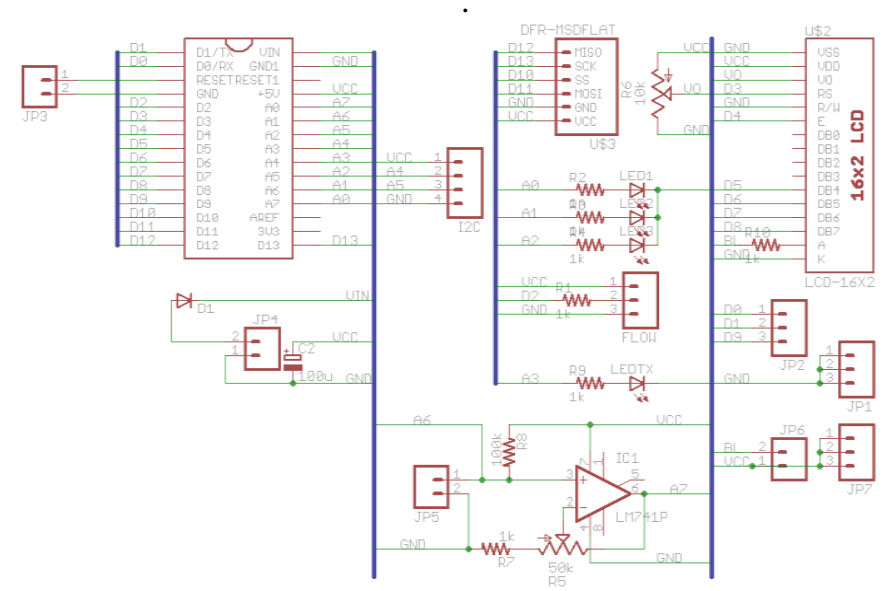

Gambar 6. Skematik perancangan sistem secara keseluruhan

\section{E. Perancangan sensor kekeruhan}

Perancangan pendeteksian kekeruhan air menggunakan sensor fotodiode dengan rangkaian sistem analog. Cara kerja rangkaian fotodiode yang digunakan untuk mengukur tingkat kekeruhan (turbidity) air, yaitu dengan melewatkan air diantara LED dan fotodiode. Karena keluaran tegangan yang dihasilkan fotodiode sangat kecil maka digunakan penguatan operasional menggunakan IC LM741 yang mempuyai satu saluran keluaran tegangan dengan prisip penguatan noninverting dimana pada rangkaian Gambar 7. Nilai R2 mempengaruhi nilai penguatan pada keluaran tegangan. Intesitas cahaya yang diterima fotodiode diubah menjadi sinyal tegangan yang masuk pada pin A7 Arduino. Sinyal tegangan ini akan menjukan nilai yang sebanding dengan nilai kekeruhan air yang terukur.

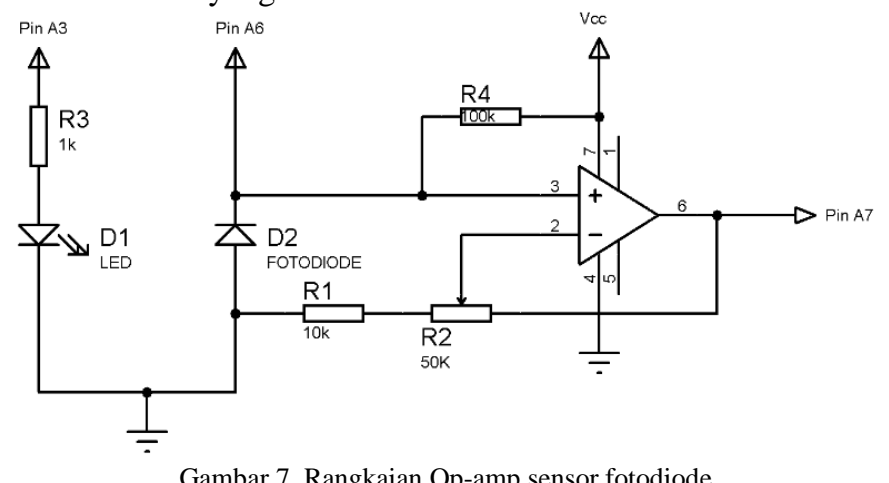

\section{H. Perancangan program sensor aliran air}

Perancangan program pada sensor aliran air digunakan untuk menghitung kecepatan aliran air atau debit yang diproses oleh mikrokontroler ATM3ga328. Kecepatan air tersebut dapat diperoleh melalui rumusan.

$$
\mathrm{Q}=\frac{\text { Jumlah pulsa permenit }}{7,5}
$$

Dimana konstanta nilai 7,5 merupakan konstanta frekuensi pada datasheet sensor, sedangkan untuk mendapatkan volume air dalam meter kubik digunakan rumusan sebagai berikut.

$$
\text { Volume }=\frac{\mathrm{Q} / 60}{1000}
$$

\section{Keterangan:}

Volume $=$ Jumlah volume air yang terukur $\mathrm{m}^{3}$

$\mathrm{Q}=$ kecepatan aliran air

$60=$ detik
$1000=$ pembagian nilai liter ke meter kubik

Untuk melihat proses jalannya program dapat dilihat pada Gambar 8 yang menunjukkan diagram alir sistem.

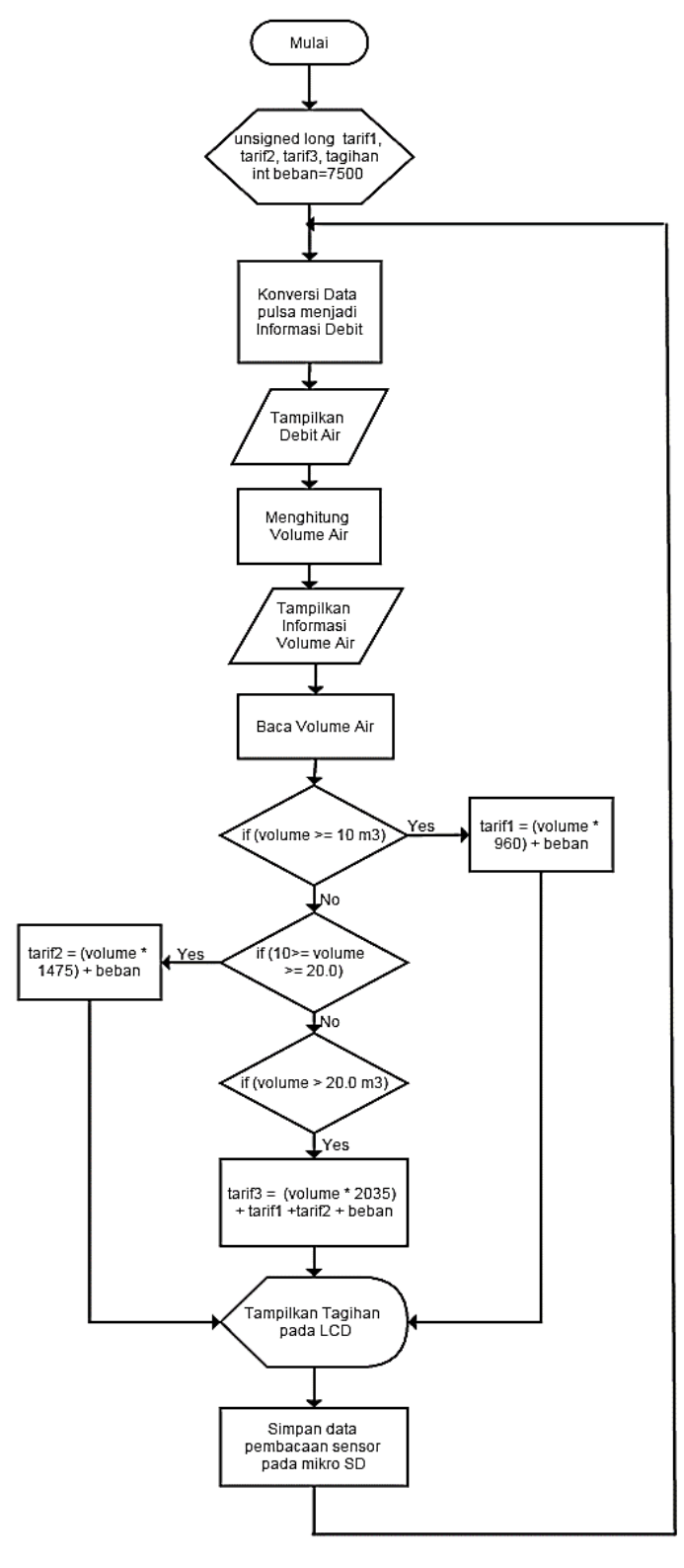

Gambar 8. Diagram alir fungsi sensor aliran air

Diagram alir di atas mempuyai tahap-tahap sebagai berikut.

1) Mula-mula dengan menginialisasi seluruh pin perangkat keras yang digunakan untuk menjalankan program seperti pin untuk membaca sensor aliran air dan pin LCD untuk menampilkan informasi pembacaan.

2) Kemudian, dilakukan perhitungan kecepatan aliran air berdasarkan rumus yang terdapat pada (3.1), hasil dari perhitungan tersebut akan ditampilkan pada layar.

3) Setelah itu, dari hasil perolehan kecepatan aliran air kemudian dimasukan pada rumusan untuk mencari volume air sesuai dengan persamaan (3.2).

4) Hasil dari perhitungan volume air tersebut selanjutnya, dilakukan proses perhitungan tarif pembayan air berdasarkan kategori penggunaan dengan penambahan abondemen atau beban ditiap kategori biaya.

5) Terakhir, setiap hasil pembacaan sensor akan disimpan pada kartu memori mikro SD dalam kurung waktu tertentu. Karena program bekerja pada fungsi void loop terus berulang-ulang. 
Tabel 4. Ketegori tarif penggunaan air golongan rumah tangga

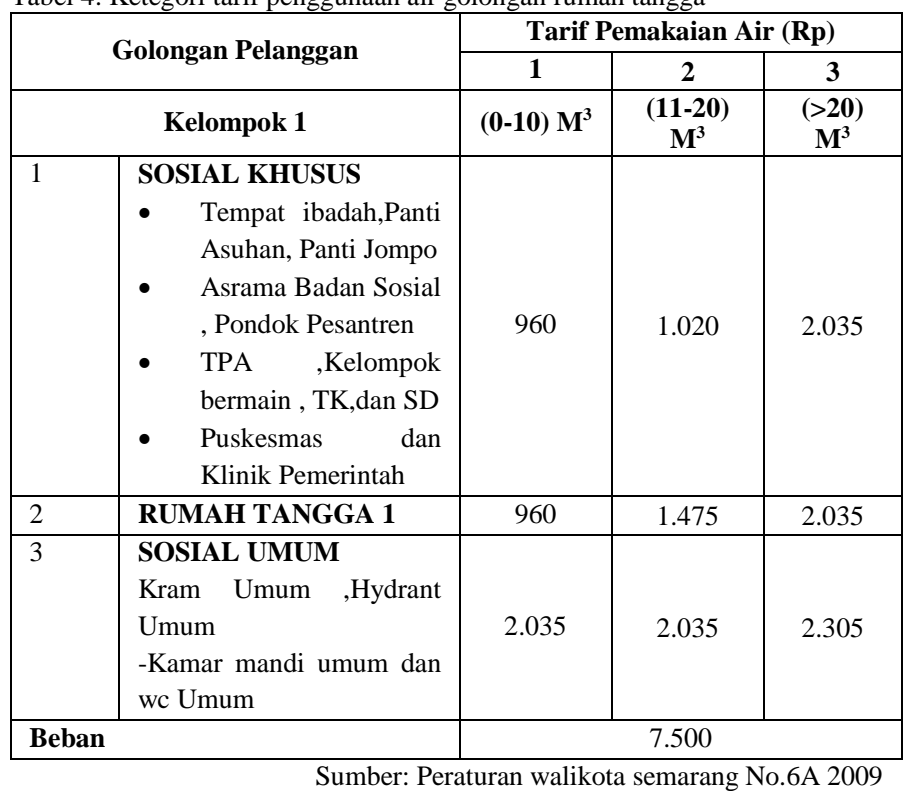

Dalam perancangan pendeteksian kekeruhan air menggunakan sensor fotodiode, sensor akan aktif jika kecepatan aliran air atau debit berada pada kondisi nol yang berarti air dalam keadaan diam sehingga tidak menggangu proses pemacaan sensor akibat terjadinya gelembunggelembung air yang mengalir, kemudian LED akan menyala dan mengaktifkan pembacaan pada sensor fotodiode yang dibaca melaui ADC (Analog Digital Converter) yang mengubah sinyal tegangan ke bentuk bit-bit mikrokontroler, kemudian nilai tersebut dikelompokan menjadi tiga kategori variabel linguistik yaitu jernih, keruh dan sangat keruh. Untuk diagram alir program dapat dilihat pada Gambar 9.

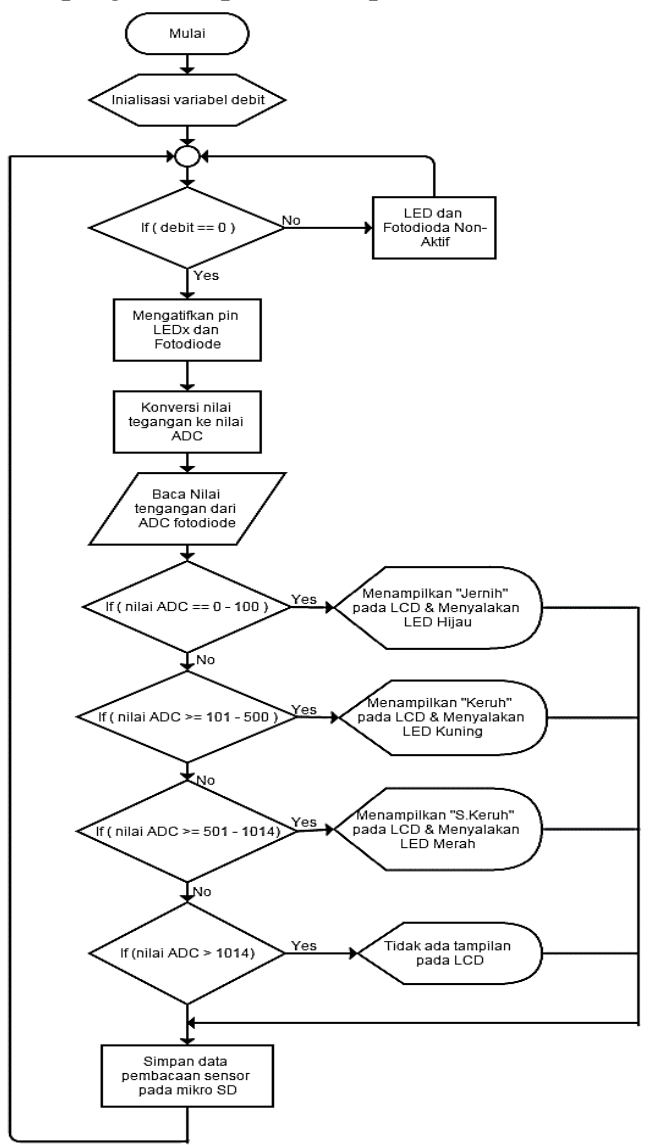

Gambar 95. Diagram alir fungsi pendeteksian kekeruhan air
Pada perancangan sistem pengukuran kekeruhan air ini digunakan resolusi ADC 10-bit yang berarti ketelitian pembacaan data mencapai maksimum $2^{10}-1=1023$. Prinsip kerja untuk mendapatkan nilai ADC dengan rasio perbandingan sinyal masukan dan tegangan referensi dikalikan dengan resolusi bit.

$$
\text { Nilai ADC }=\frac{\mathrm{V}_{\text {in }} \times \text { Bit }}{V_{\text {ref }}}
$$

Sedangkan untuk mencari nilai tengangan keluaran ADC dengan menggunakan rumus.

$$
\mathrm{V}_{\text {out }}=\frac{\text { Nilai ADC }}{\text { Bit }} \times \mathrm{V}_{\text {ref }}
$$

\section{Perancangan Modul kartu mikro SD}

Modul kartu SD yang digunakan pada perancangan ini mendukung penggunaan kartu mikro SD yang biasa digunakan pada perangkat bergerak. Fungsi dari penggunaan karu SD sebagai datalogger untuk menyimpan proses pembacaan sensor. Karena mikro SD bekerja pada tegangan 3.3 V maka dibutuhkan rangkaian pembagi tengangan dari masukan Arduino sebesar 5 V. Berikut merupakan rencangan penggunaan pin Arduino pada modul mikro SD seperti yang terlihat pada Tabel 5 .

Tabel 5. Penggunaan pin modul kartu SD pada Arduino

\begin{tabular}{|l|c|}
\hline \multicolumn{1}{|c|}{ Pin Modul Kartu SD } & Pin Arduino \\
\hline MISO (Master In Slave Out) & D12 \\
\hline SCK (Serial Clock) & D13 \\
\hline SS (Slave Select) & D10 \\
\hline MOSI (Master Out Slave In) & D11 \\
\hline GND (Ground) & GND (-) \\
\hline VCC & VCC (+) \\
\hline
\end{tabular}

\section{IMPLEMENTASI DAN PENGUJIAN}

\section{A. Implementasi perangkat keras}

Pengimplementasian perangkat keras merupakan tahap perealisasian desain kebentuk yang nyata. Hal ini dimulai dengan penentuan komponen apa saja yang akan digunakan, setelah itu membuat papan sirkuit atau yang biasa dikenal dengan istilah PCB (Printed Circuit Board). Fungsi PCB disini yaitu untuk menghubungkan tiap-tiap komponen perangkat keras menjadi kesatuan terpadu. Gambar 10 menunjukkan hasil pembuatan papan sirkuit berdasarkan desain yang telah dibuat.

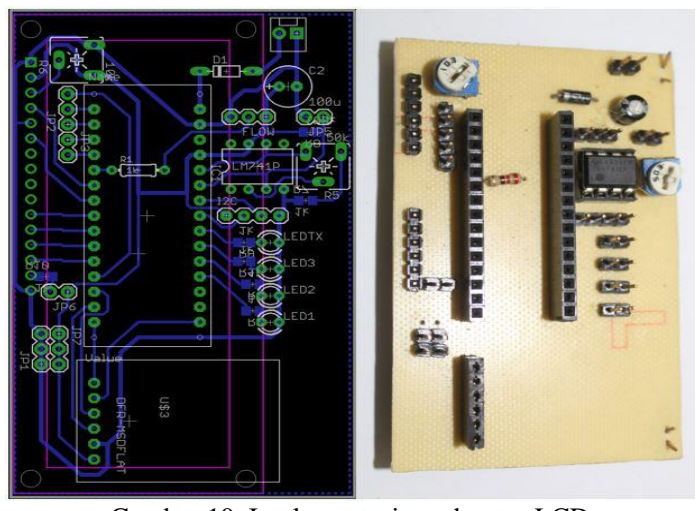

Gambar 10. Implementasi pembuatan LCD 


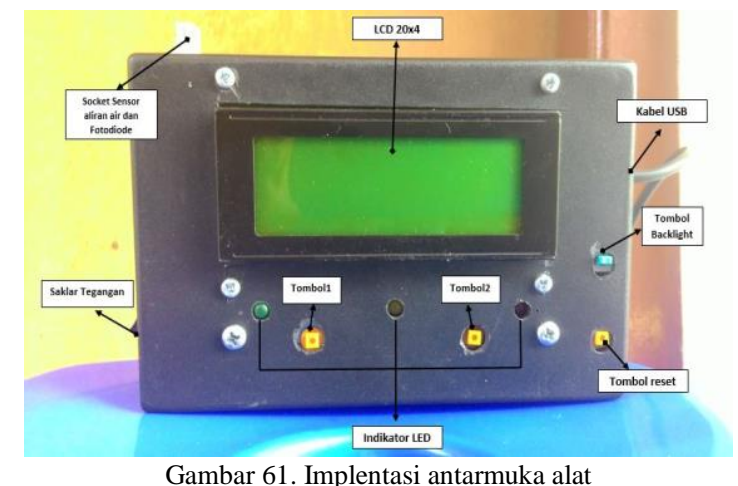

Gambar 61. Implentasi antarmuka alat

\section{B. Pengujian Sensor Aliran Air}

Pengujian pada sensor aliran air dilakukan berdasarkan pada konstruksi mekanik pemasangan sensor aliran air pada sebuah pipa. Tujuan dari pengujian ini ialah untuk mengetahui apakah aliran air yang didorong oleh pompa berjalan secara konstan.

Tahap prosesdur yang dilakukan untuk mengukur kecepatan air dengan mengaktifkan pompa air yang tersambung pada sensor melalui media pipa paralon. Sehingga, air dapat mengalir secara berlanjut. Kemudian keluaran air ditampung pada gelas ukur dengan durasi pengukuran 60 detik mulai pada saat pompa dinyalakan hingga pompa dimatikan, selajutnya akan dilihat volume air yang terukur. Berikut merupakan hasil pencatatan pengujian sensor aliran air pada serial monitor berdasarkan pulsa dan waktu tunda.

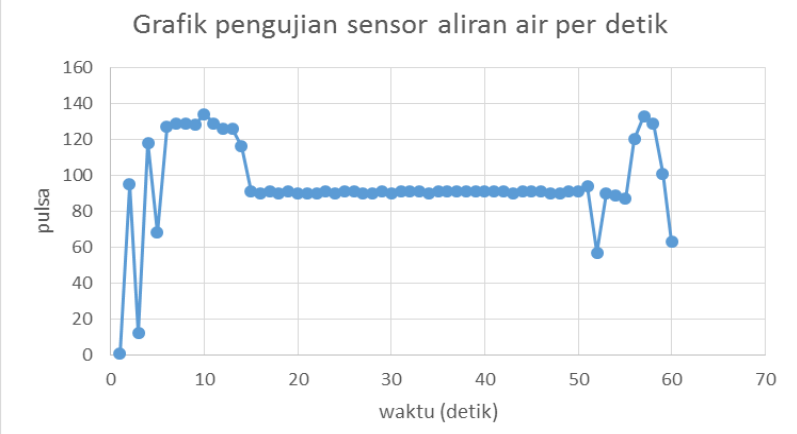

Gambar 12. Grafik pengujian sensor aliran air

Grafik tersebut menujukan putaran rotor yang terdapat pada sensor mulanya mengalami kenaikan fluktuasi dikarenakan tekanan pada pompa yang belum stabil, kemudian setelah didetik ke 19 menujukan kestabilannya seiring waktu karena tekanan pada air sudah mulai konstan dan ketika pompa mulai dinon-aktifkan rotor mengalami degradasi pulsa akibat pengaruh suplai air telah dihentikan. Sehingga dapat disimpulkan bahwa sensor bekerja dengan baik berdasarkan tekanan air yang mengalir. Untuk hasil akurasi pengukuran volume air dapat dilihat pada Tabel 6 .

Tabel 6. Hasil pengujian akurasi sensor aliran air

\begin{tabular}{|c|c|c|c|c|}
\hline Pengujian & $\begin{array}{c}\text { Volume ukur } \\
\text { sensor } \\
\text { (liter/menit) }\end{array}$ & $\begin{array}{c}\text { Volume air } \\
\text { (liter/menit) }\end{array}$ & Error & Akurasi \\
\hline 1 & 12,7 & 10,5 & $1,17 \%$ & $98,83 \%$ \\
\hline 2 & 13,1 & 13,2 & $1,21 \%$ & $98,79 \%$ \\
\hline 3 & 13,3 & 13,1 & $1,23 \%$ & $98,77 \%$ \\
\hline 4 & 13,2 & 13,0 & $1,22 \%$ & $98,78 \%$ \\
\hline 5 & 13,1 & 12,8 & $1,21 \%$ & $98,78 \%$ \\
\hline Rata-Rata & 13,08 & 12,52 & $1,20 \%$ & $98,80 \%$ \\
\hline
\end{tabular}

Dari hasil pengujian yang dilakukan selama lima kali percobaan diketahui bahwa akurasi pengukuran sensor mencapai 98,80\% dari volume air sebenarnya. Hasil tersebut menujukan bahwa ketelitian sensor hampir mendekati volume ukuran sebenarnya dengan error yang didapat 1,20\%. Sehingga dapat disimpulkan bahwa kemampuan sensor cukup handal.

Adapun beberapa faktor yang mempengaruhi ketidak akuratan dalam melakukan penelitian ini seperti terdapat suatu kondisi udara yang hampa mengerakan rotor pada sensor ketika pompa mulai di non aktifkan, sehingga sensor menunjukkan volume yang lebih dalam pengukuran sebenarnya serta ketepatan dalam mengukur volume pada gelas penampung.

\section{Pengujian sensor fotodiode}

Untuk mendeteksi kekeruhan air digunakan sebuah sensor fotodiode sebagai penerima (receiver) dan LED sebagai pemancar cahaya (transmitter) berkuran $5 \mathrm{~mm}$. Kedua komponen tersebut diletakkan pada bagian pipa paralon dengan jarak kedua komponen $1,5 \mathrm{~cm}$. Supaya proses pembacaan lebih presisi mendapatkan radiasi cahaya penempatan fotodiode dan LED di hadapkan secara sejajar.

Prosedur pengujian kekeruhan air didasarkan atas perbandingan sampel air yang telah diukur menggunakan dua perbandingan alat, yakni alat yang dibuat dan alat turbiditymeter merek Mikro TPW dengan satuan pengukuran NTU. Dimana pada alat ukur tubiditymeter ini mengunakan metode perbandingan cahaya yang tersebar pada sampel larutan suspensi, jadi semakin tinggi intensitas cahaya yang tersebar maka semakin tinggi kekeruhan air. Skala pembacaan alat ini mulai dari 0 - 1000 NTU. Cairan yang digunkan pada percobaan ini yakni air yang dicapurkan dengan tanah liat sehingga air mengalami kekeruhan. Untuk sampel air dapat dilihat pada Gambar 13. Pengujian dilakukan di Lab Teknik Lingkungan, Universitas Diponegoro.

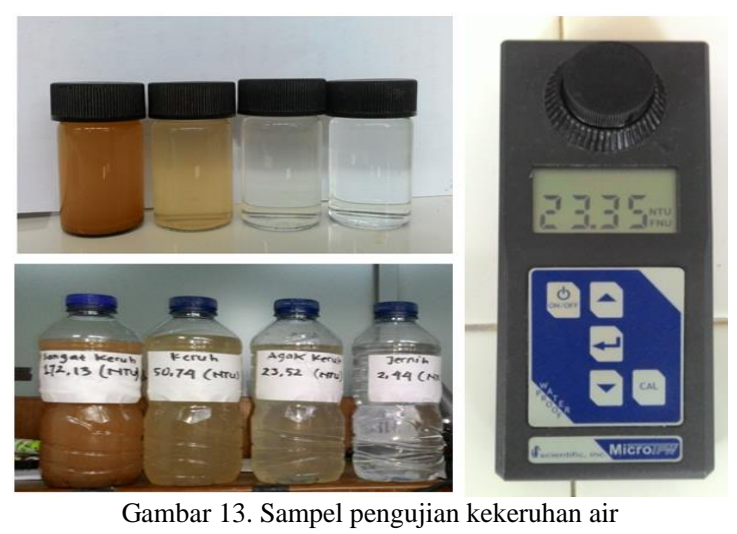

Tabel 7. Hasil kalibrasi alat dengan turbiditymeter merek Mikro TPW

\begin{tabular}{|l|l|l|l|l|}
\hline \multirow{2}{*}{$\begin{array}{l}\text { Variabel } \\
\text { Linguistik }\end{array}$} & Tubiditymeter & Fotodiode & Pengukuran & \multirow{2}{*}{ Error } \\
\cline { 2 - 4 } Jernih & 0,01 & \multicolumn{1}{|c|}{ Volt } & NTU & \\
\hline & 2,44 & 0,19 & 7,16 & $99,9 \%$ \\
\hline & 4,23 & 0,21 & 7,89 & $69,1 \%$ \\
\hline Keruh & 10,01 & 0,25 & 9,36 & $54,8 \%$ \\
\hline & 23,52 & 0,32 & 11,93 & $16,1 \%$ \\
\hline & 45,52 & 0,62 & 12,66 & $85,7 \%$ \\
\hline & 51,23 & 1,07 & 39,45 & 29,94 \\
\hline Sangat & 144,8 & 3,91 & 143,64 & $0,8 \%$ \\
\hline
\end{tabular}

JTsiskom - 84 


\begin{tabular}{|l|l|l|l|l|}
\hline Keruh & & & & \\
\hline & 150,6 & 3,97 & 145,84 & $3,3 \%$ \\
\hline & 153,4 & 4,34 & 159,42 & $3,8 \%$ \\
\hline & 164,1 & 4,42 & 162,35 & $1,1 \%$ \\
\hline & 172,13 & 4,86 & 178,49 & $3,6 \%$ \\
\hline
\end{tabular}

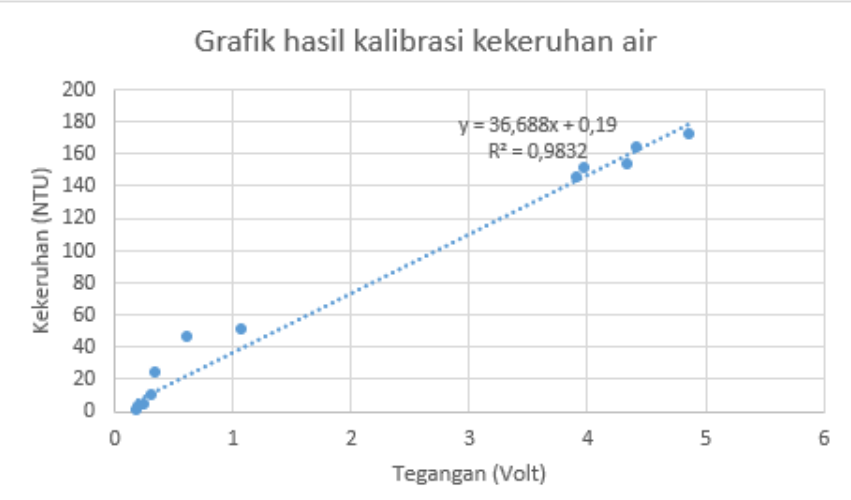

Gambar 14. Grafik hasil kalibrasi alat pengukur kekeruhan air

Nilai regresi linear didapatkan pada Gambar 14 mendapatkan persamaan $y=36,688 x+0,19$. Dimana $x$ adalah variabel independent yang mewakili nilai tegangan, sedangankan y merupakan variabel dependent dari nilai kekeruhan air (NTU). Nilai koefisien deterrminasi $\left(r^{2}\right)$ mencapai 0,9832 yang berarti dari persamaan data tersebut diperoleh hasil data yang cukup baik. Sedangakan nilai intercept menunjukan nilai 0,19 volt dari tegangan. Adapun hasil ketelitian pembacaan sensor dipengaruhi oleh jarak fotodiode dengan LED, sehingga ditetapkan nilai awal pembacaan sensor berada pada nilai tegangan 0,19 volt. Tabel 8 menunjukan hasil pengukuran alat dan error yang di dapatkan berdasarkan perbadingan sampel air yang terukur.

\section{Pengujian modul kartu SD}

Proses pengujian modul kartu SD mula-mula dengan memasukan pustaka kartu SD yang telah terdapat pada perangkat lunak Arduino IDE seperti \#include <SD.h>. Setelah itu, dilakukan inialisasi pin SS (D10) untuk mengaktifkan proses pembacaan dan penulisan level tegangan sesuai dengan konfigurasi Master-Slave melalui protokol komunikasi SPI. Setelah memori dikenali maka proses untuk melakukan penulisan pada mikro SD dapat dilakukan, jika tidak maka sistem akan menapilkan pada layar LCD bahwa memori berlum terpasang.

Hasil penulisan informasi pada kartu memori mikro SD berupa berkas dengan nama Test.txt yang terekam setiap 60 detik secara otomatis ketika sistem dinyalakan. Kapasitas memori yang digunakan sebesar untuk menampung data sebesar 4 GB. Untuk hasil parameter keberhasilan dapat dilihat pada Tabel 8, sedangkan hasil penulisan berkas dapat dilihat pada Gambar 15 .

Tabel 8. Parameter keberhasilan kartu SD

\begin{tabular}{|c|l|c|}
\hline No & Parameter keberhasilan & Keterangan \\
\hline 1 & $\begin{array}{l}\text { Sistem dapat mendeteksi kartu } \\
\text { memori mikro SD yang terpasang. }\end{array}$ & Berhasil \\
\hline 3 & $\begin{array}{l}\text { Sistem dapat menulis pada berkas } \\
\text { pada kartu memori mikro SD. }\end{array}$ & Berhasil \\
\hline 4 & $\begin{array}{l}\text { Sistem dapat membaca isi berkas } \\
\text { yang telah terekam pada kartu } \\
\text { memori mikro SD. }\end{array}$ & Berhasil \\
\hline
\end{tabular}

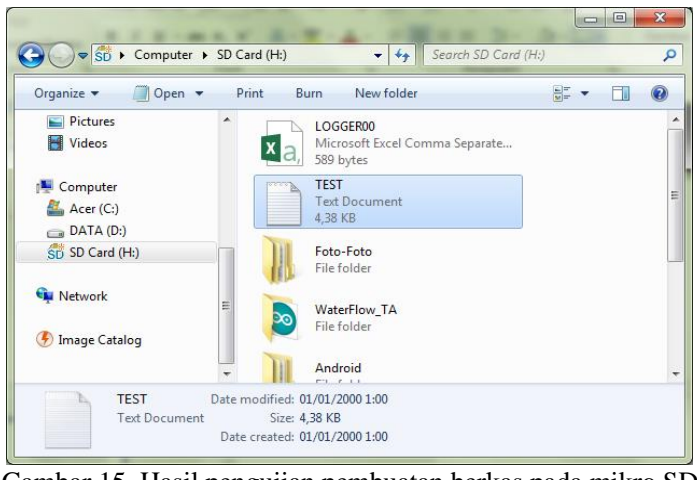

Gambar 15. Hasil pengujian pembuatan berkas pada mikro SD

E. Pengujian program perhitungan biaya volume air

Proses pengujian program perhitungan biaya berdasarkan kategori penggunaan rumah tangga terdiri dari tiga keadaan.

1) Jika volume lebih kecil sama dengan $10 \mathrm{~m}^{3}$ digunakan perhitungan.

Tarif1 $=($ Volume $\times 960)+$ beban

2) Jika volume antara lebih besar dari $10 \mathrm{~m}^{3}$ dan sama dengan $20 \mathrm{~m}^{3}$ digunakan perhitungan.

Tarif2 $=($ Volume $\times 1475)+$ beban

3) Jika volume lebih besar dari $20 \mathrm{~m}^{3}$ digunakan perhitungan.

Tarif3 $=($ Volume $\times 2035)+$ beban

Total tagihan $=(9600+29500)+$ Tarif3

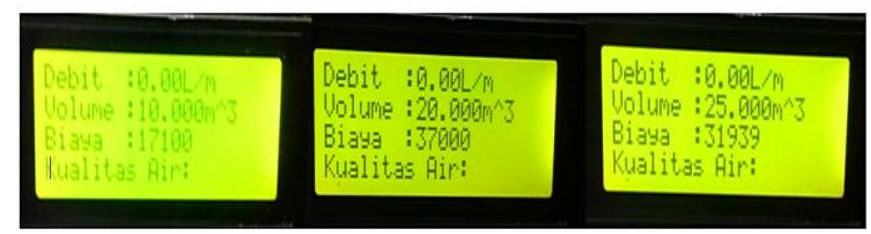

(a)

(b)

(c)

Gambar 16. Pengujian kalkulasi biaya volume air

Gambar.20 menunjukkan hasil dari perhitungan tiap tarif. Gambar (a), menujukan hasil perhitungan biaya jika volume air $\geq 10 \mathrm{~m}^{3}$ dan Gambar (b) menujukan hasil perhitungan jika volume air berada pada jarak $>10 \mathrm{~m}^{3}$ sampai dengan $\geq 20$ $\mathrm{m}^{3}$, sedangkan Gambar (c) hasil perhitungan menujukan penggunaan volume di atas $20 \mathrm{~m}^{3}$. Dengan nilai beban $=7500$. Untuk hasil uji coba alat yang dilakukan dengan mengukur volume yang ditampung selama 60 detik. Hasil yang diperoleh diketahui volume air yang tertampung sebanyak $0,013 \mathrm{~m}^{3}$ atau 13 liter.

\section{Grafik Biaya vs Volume}

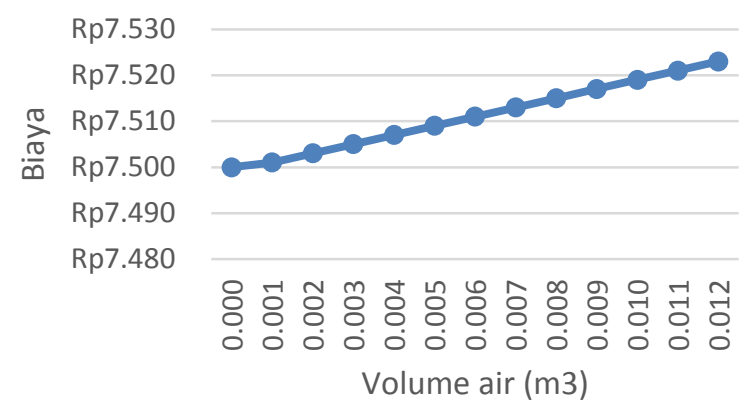

Gambar 17. Grafik hubungan volume dan biaya

Gambar 17 menujukan grafik linieritas antara biaya dan volume dari pengkonversian volume air ke biaya yang dihasilkan. Dimana biaya didapatkan dari volume, volume 
didapatkan dari debit dan debit didapatkan dari pulse. Sehingga, grafik tersebut dapat disimpulkan bahwa sering volume bertambah, biaya yang dikenakan juga akan semakin bertambah sesuai dengan rumusan yang telah diberikan pada program. Hasil tersebut dicapai dengan waktu pengukuran selama 60 detik.

\section{KESIMPULAN DAN SARAN}

\section{A. Kesimpulan}

Dari hasil pengujian dan percobaan pengukuran yang dilakukan dari purwarupa instrument sistem monitoring digital penggunaan air PDAM dan kualitas kekeruhan air ini, maka dapat disimpulkan bahwa.

1 Alat ini mampu menampilkan pulse, debit air, volume air, biaya, dan kualitas kekeruhan air secara digital yang diharapkan bisa memudahkan pelanggan dalam memantau penggunaan dan kualitas air yang mereka gunakan. Sehingga pelanggan tidak perlu khawatir pada saat di loket harus membayar dengan biaya yang tak terpikirkan sebelumnya.

2 Telah dilakukan uji coba kalibarasi dengan pengukuran volume air secara konvensional dengan menampung volume air dalam kurung waktu tententu pada sebuah gelas ukur dan didapatkan akurasi yang cukup baik yakni sekitar 98,8 \% dan untuk kalibrasi sensor fotodiode sebagai detektor kekeruhan air diperoleh sampel data air yang sesuai dengan alat pengujian alat tubiditymeter dengan batas deteksi maksimal kekeruhan air pada alat ini mencapai sekitar 173 NTU, sehingga bisa dikatakan alat ini berkerja cukup baik untuk mendeteksi standar kekeruhan air.

3 Pada alat ini tersedia media penyimpanan data yakni kartu memori mikro SD yang berfungsi melakukan penyimpanan data pembacaan variabel keluaran secara otomatis setiap 60 detik dalam bentuk format data ".txt".

4 Sumber daya yang dibutuhkan untuk mengatifkan alat ini bisa menggunakan adaptor 6 - 12 Volt.

\section{B. Saran}

Tentunya pada alat yang dibuat ini masih mempuyai banyak kekurangan oleh karena itu disarankan untuk dapat menambahkan komponen RTC (real time clock) agar dapat merekam pembacaa data sensor berdasarkan waktu dan tanggal. Adapun hal lain yaitu dapat dikembangkan ke teknologi yang saat ini menjadi tren monitoring ke arah smarthome dan energy meter.

\section{DAFTAR PUSTAKA}

[1] Asdak, Chay., Hidrologi dan Pengelolahan Daerah Aliran Sungai. UGM-Press, Yogjakarta, 1995.

[2] Banzi, Massimo., Getting Started With Arduino. Sebastopol: O'Reilly Media, Inc, 2008.

[3] Clair N. Sawyer, Perry L. McCarty., Chemistry for Environmental Engineering (4th ed.), McGraw-Hill, New York, 1978.

[4] Kadir, Abdul., Panduan Praktis Mempelajari Aplikasi Mikrokontroler dan Pemrogramannya, Gramedia, Jakarta, 2013.

[5] Khopkar, S.M., Konsep Dasar Kimia Analitik. UI-Press, Jakarta, 2003.

[6] Hefni, E., Telah Kualitas Air Bagi Pengelolahan Sumber Daya dan Lingkungan Perairan, Kanisius Media, Yogyakarta, 2003.

[7] Lawler, D.M., Turbidimetry and Nepheleometry In Encylopedia of Analytical Science, Academic Press Ltd, UK, 1995.

[8] Lenore S. Clescerl, Arnold E. Greenberg, and Andrew D. Eaton. Standard Methods for Examination of Water \& Wastewater (20th ed.), American Public Health Association. Washington, DC, 1998.

[9] Malvino, A. P., Prinsip-prinsip dan Penerapan Digital, Diterjemahkan oleh Ir.Irwan Wijaya. Erlangga, Jakarta, 1992.

[10] Mulyono. Kamus Kimia, Bumi Aksara, Jakarta, 2007.

[11] Setiawan, Imam., Buku Ajar Sensor dan Tranduser, Universitas Diponegoro, Semarang, 2009.

[12] Soewarno., Hidrologi Pengukuran dan Data Pengelolahan Aliran Sungai (Hidrometri), NOVA, Bandung, 1995.

[13] Sutrisno, C.Totok., Teknologi Penyediaan Air Bersih, Rineka. Cipta, Jakarta, 2004.

[14] Wilson, J. Sensor Technology, Handbook. Newnes Elsevier, USA, 2005.

[15] World Health Organization., Guideline for dringking-water quality Vol.1 Recommendations. WHO Library, Switzerland, 2006.

[16] Armaini, Fitria., Rancang bangun alat ukur volume air PDAM berbasis mikrokontroler AT89S51 dengan sensor fotodioda, Universitas Andalas, Padang, 2011.

[17] Ika, Nike., Perancangan dan pembuatan Alat ukur kekeruhan air berbasis Mikrokontroler 8535. ITS, Surabaya, 2013.

[18] Kusumawardana, D., Valuasi Ekonomi Air Bersih Surabaya, DisertasiS3, Universitas Gadjah Madah, Yogjakarta, 2010.

[19] Lambrou, T.P, C.C.Anastasiou and C.G. Panayiotou, "A Nephelometric Turbidity System for Monitoring Residential Drinking Water Quality", in the 1st International Conference on Sensor Networks Applications, Experimentation and Logistics, SensAppeal, 2009.

[20] Latif, Maulana., "Instrumen Pengukur Kalor-Jenis Air", Skripsi-S1, Universitas Indonesia, Depok, 2011.

[21] ---, Diklat Tenaga Teknik Penyediaan Air Minum, PERPAMSI \& ITB, Bandung, 1994

[22] Keputusan Menteri Kesehatan Republik Indonesia. Tentang Pensyaratan Kualitas Air Minum., No. 907/Menkes/SK/VII/2002.

[23] Peraturan Walikota Semarang 6A., Tentang Penetapan Tarif Air Minum pada Perusahaan Daerah Air Minum (PDAM), Kota Semarang, 2001.

[24] Peraturan Menteri PU, Tentang Penyelenggaraan Pengembangan Sistem Penyediaan Air Minum Pengukuran Debit Aliran., No.18PRT/M/2007.

[25] Arduino Website. http://arduino.cc/en/Reference/HomePage

[26] Water Flow Sensor Datasheet, http://www.seeedstudio.com/wiki/G1/2_Water_Flow_sensor, diakses pada tanggal, 4 Juni 2014. 